\title{
EVALUATING AGAINST A MULTI- DIMENSIONAL ECONOMIC GOAL: A SUSTAINABLE AND PROSPEROUS SOCIALISM
}

\author{
Al Campbell \\ University of Utah
}

\begin{abstract}
Al Campbell is a retired Professor Emeritus of Economics from the University of Utah. Relative to Cuba, he is an Editor of this journal. Besides his ongoing research on the political economy of the Island, he is particularly interested in providing platforms for Cubans to be part of the international academic discussion on Cuba, to present their ideas on what is happening in their country. His edited Cuban Economists on the Cuban Economy (2013, University Press of Florida), and the currently contracted book on cooperatives in Cuba, are collections of works by Cuban authors on these subjects, translated for presentation to the English-speaking world.
\end{abstract}

\begin{abstract}
The concept of evaluation of any existing or proposed policy only has meaning in relation to some goal. Further, if the goal used for the evaluation is not the actual goal of the actor involved, any conclusions about the effectiveness or appropriateness of the policies are irrelevant for that actor. It is very common for people around the world to evaluate the economic policies of Cuba relative to claimed effects on the rate of growth of Gross Domestic Product (GDP), followed by discussions on what the real effect on the GDP of the policies has been or will be. Given that Cuba has very explicitly stated that its economic goal is a prosperous, sustainable socialism, such considerations cannot constitute economic evaluations of policies for the country. A proper evaluation is, however, complicated by the multi-dimensional nature of the Island's economic goal. This article considers six of Cuba's most fundamental and
\end{abstract}


commonly discussed economic policies as examples, to argue that in practice it is very often, though not necessarily always, possible to design policies in such a way that their evaluation relative to all the dimensions of Cuba's economic goal does not involve the potential problem of the "trade-off between dimensions" inherent to any multi-dimensional goal.

Keywords: Cuba, Cuban economy, socialism, Cuban economic goals, Cuban economic performance, multi-dimension goals

[Alice] "Would you tell me, please, which way l ought to go from here?"

"That depends a good deal on where you want to get to," said the [Cheshire] Cat.

(Carroll 1865: 57)

Over the last three decades, Cuba has been slowly developing a new economy. It is still very much a project "in progress". A plethora of proposals has been generated by many different people over the years, both ones that are consistent with and support the government's general approach, and ones that argue that a different approach would be better for Cuba's economy.

The briefer first section of this work systematically discusses in general the methodological issues involved in evaluating an economic policy against a multidimensional goal. The issues addressed here apply to any country with a multidimensional economic goal, and hence to the country that this article is concerned with, Cuba. With the general methodological issues established by the first section, the longer second section then illustrates, using six concrete examples, how economic policies for Cuba must be evaluated. These examples are among the most fundamental and commonly discussed policies for improving Cuba's economy, from among the much larger number of proposals that are continuously being generated.

\section{Evaluating Economic Policies Against a Cuba Multi-Dimensional Goal}

The consideration of the methodological issue of evaluating an economic policy in relation to multi-dimensional economic goal will be presented in four steps. The first step will briefly establish that the very concept of evaluation itself requires a goal for the evaluation to carried out against. Then in this frame of the need in general for a goal in order for evaluation to be possible, 
the second step will present Cuba's particular and clearly stated economic goal. The third step will highlight an inherent and unavoidable problem that arises in general when the goal that is being evaluated is multi-dimensional, as is the case for Cuba. This problem will be illustrated with two economic examples, the Human Development Index (HDI), and the performance of the United States Federal Reserve Bank (the country's Central Bank). The final step will then briefly describe a special case where the multi-dimensionality of the goal does not pose the general problem for ranking policies indicated in step three, and evaluations of which policies are preferred or "better" can proceed just as for any one-dimensional goal. This whole first section will establish the background for discussing in the second section six of the most fundamental and commonly debated policies for improving Cuba's economy, as illustrations of what must be done for appropriate evaluations against the Island's multidimensional economic goal.

\section{The Evaluation of Any Economic Policy}

The concepts of a policy being economically "good" or "better than another" only make any sense in relation to some goal, regardless of whether or not the goal is explicitly stated. Hence the evaluation of any economic policy as "good" or "better" (or "bad" or "worse") requires the existence of an economic goal, stated or not, that the evaluation implies will be well (or poorly) promoted by the policy. Expressed aphoristically; “you can't know what will help you, if you don't know what you want".

\section{Cuba's Economic Goal}

Different from almost any other country, Cuba at this moment in history has a small number of official documents that explicitly indicate, in broad and general terms, its economic goal, and the general nature of policies that it believes are well suited to achieve that goal. As the Cuban government continually stresses, including by their very names as "guidelines", these documents are not intended to be viewed as the Ten Commandments handed down to Moses by God, rigid and permanent. Rather, they are summaries at a given moment of the government's thinking, informed by formal broad social discussions about the direction of Cuba's ongoing economic reform process. As such, they are ideas which must be continually updated. It was a major event in the unfolding of the new economy of Cuba when the first version of these guidelines appeared in 2011, the Lineamientos de la Politica Económica y Social del Partido y la Revolución (PCC 2011) (commonly called the 
Lineamientos). In 2016/171 three new documents both updated and extended the Lineamientos: the Conceptualización del Modelo Económico y Social Cubano de Desarrollo Socialista (PCC 2017a) (hereafter Conceptualización), the Plan Nacional de Desarrollo Económico y Social hasta 2030: Propuesta de Visión de la Nación, Ejes y Sectores Estratégicos (PCC 2016a) (hereafter Plan 2030), and the Lineamientos de la Política Económica y Social del Partido y la Revolución para el Periodo 2016-2021 (PCC 2017b) (hereafter Lineamientos 2016-2021).

Since the publication of the guiding documents from 2016/17, a sound-bite phrase has come to be used in Cuba to represent the multi-dimensional goal that its economy has had since 16 April 1961: "a prosperous and sustainable socialism". ${ }^{2}$ This phrase will be used throughout this work to indicate Cuba's

1 I refer to them here as from 2016/17 because, while they were famously adopted at the 7th Party Congress in April 2016, two of them were not ratified in their final form in which they serve as the current guidelines for Cuba's unfolding political economy until 2017. See PCC (2016a, 2016b) for the versions of the three documents approved by the 7 th Party Congress. Subsequent to that congress the documents were submitted to an extended popular discussion and consultation in many fora, in which a total of 1.6 million Cubans participated (Cuba had 9.3 million registered voters as of February 2019 (IFES 2020)) and from which numerous modifications were made to the three documents. In their updated forms, in May 2017 "the three guiding documents on the updating of the Cuban economic and social model were approved by the Third Plenum of the Communist Party of Cuba Central Committee" (Granma 2017). That Plenum then informed the deputies of the highest body of state power, the National Assembly of People's Power, of the ongoing updating of the Plan 2030, and submitted the updated Conceptualización and the Lineamientos 2016-2021 to them for approval as "the guiding foundations of the work of all state and government entities and officials, our workers and the people in general" (NAPP 2017). For a brief newspaper report on more recent developments in the Plan 2030 (and the evaluation of the implementation of the Lineamientos 2016-2021 as of then), see Granma (2019).

2 This phrase clearly has three components, and hence any economic proposals must consider all three dimensions; socialism, prosperity and sustainability. For reasons of space and given its goal of methodological illustration, this work will illustrate its theme of the need to consider more than the ubiquitously considered goal of prosperity to properly evaluate any economic policies for Cuba, by hereafter using only the two dimensions of socialism and prosperity. In actual practice the third dimension of sustainability must be considered as well. For a seven-paragraph short official indication of how the whole phrase encompassing all three dimensions is used in the guiding documents (and from that in today's discussions in Cuba), see the first entry into the glossary of terms appended to the published document that includes both the Conceptualización and the Plan 2030 as they were submitted to the 7th Party Congress in 2016 (PCC 2016a: 28). 
economic goal. It will be used in the evaluation of the existing and the proposed polices considered here, in line particularly with the three most current guiding documents from 2016/17.

Note that this paper will continually refer to "a prosperous socialism" as a single two-dimensional goal, as opposed to being "Cuba's two economic goals". Certainly this is partially a semantic distinction, as all points that will be made in this article could be made with the other usage. This usage as a single goal is employed, however, to stress what the documents make clear, that the Cuban government maintains not only the inherent compatibility of the goal's multiple dimensions, but beyond that, their mutual reinforcement.

\section{The Intrinsic Problem of Ranking with Any Multi-Dimensional Goal}

If two policies are to be compared in relation to a single objective, the procedure is theoretically ${ }^{3}$ straightforward. An evaluation is made of how much each policy would contribute toward that one-dimensional goal, and the policy that makes the greater contribution is considered to be better. If the one-dimensional economic goal was the commonly declared goal of maximising Gross Domestic Product (GDP) growth, then whichever policy yielded a greater rate of growth of this indicator would be better. If the one-dimensional economic goal was the actual goal of capitalist economies of maximising the rate of profit of their capital, whichever policy yielded a greater rate of profit would be better. But the concept of "greater" breaks down for evaluating policies in relation to a goal with two or more dimensions. If one two-dimensional vector is greater than another in one dimension and smaller in the other, it has no meaning to say that either vector is greater than the other. If one policy promotes one dimension of a two-dimensional goal more than another policy and the other dimension less (or harms it), then one cannot say which of those two policies fulfils the twodimensional goal "better". 4

Two short discussions of the United Nations' goal of human development and the US Federal Reserve's goal will concretise this point.

3 In actual policy debates there remain many grounds for disagreement, with two of the most common being arguments about the accuracy and adequacy of the data, and arguments about claims of what the proposed policies will yield.

4 If one needs to choose between two such policies in practice, which is equivalent to indicating which policy one considers to be "better", then one has to decide what one considers to be the "economic trade-off". Mathematically this is the process of assigning "weights" to the components of a vector, which reduces it to a one-dimensional quantity, as will be discussed later in this paper. This does not contradict the statement here that neither vector, as a vector, can be considered "greater". 
In the face of the long-standing critique of using the level of per capita GDP as a measure of human well-being or its rate of growth as a measure of good economic policy, in 1990 the United Nations began to publish a threedimensional measure, the Human Development Index (HDI). This considered human well-being to require good health, education ${ }^{5}$ and access to sufficient material goods and services for a dignified life (all as defined by contemporary standards). But a comparison of two alternative policies in these three dimensions poses the immediate question indicated above - which of the two policies is better, if one gives more of one dimension and less of another?

Because the HDI was intended as an alternative to GDP to inform choices between alternative proposed policies, the three one-dimensional measurable constitutive indices had to be combined somehow into a single one-dimensional index to allow the alternatives to be ranked for that purpose. The HDI index was the result of this reduction of the three dimensions into one. No theoretical justification was given for combining these three qualitative different measures in the simplest way possible, a linear combination with equal weights. The point here is not that this way is bad or that some other way is theoretically better, but rather that other plausible ways of combining them into one dimension would have given different results for the whole point of the exercise, different rankings of "which is better". The subjectively determined weights given to the various dimensions in the reduction to one dimension can be referred to as determining a "trade-off between dimensions".

The ability to change the amount that each dimension contributed to the combined index, and through that the rankings, was underlined in 2010 when the method of combining them was changed. The lack of any theoretical justification for what is "the best way" to combine these three contributions to human well-being, and the somewhat different rankings from different ways of combining, cannot however, be used to argue for accepting GDP as a better measure than HDI for country-performance comparisons on the grounds that

5 Conceptually good health is understood to contribute to one's quality of life and capacity for human development in a large number of ways, but to construct an easily computable index, some proxy for that multi-dimensional concept needed to be selected. While life expectancy is generally considered to be a goal for human well-being in itself, its inclusion in the HDI is as a proxy for the much broader multi-dimensional concept of good health. Similarly, education was not included simply as a goal in itself or for some narrow economistic reason such as access to modern jobs ("human capital"), but rather as a manageable proxy for the many dimensions of quality of life and human development that it contributes to, such as being able to access culture, or being able to participate as an active citizen in society. 
it does not have this lack of uniqueness, as many of its advocates try to do. To use just GDP as a measure of well-being, as is still widely done, amounts to nothing more in this broader frame of these three dimensions of well-being than to assigning $100 \%$ weight to the GDP contribution and $0 \%$ to the other two contributions. Given the broad social agreement that those other two dimensions are important components of human well-being, a method that completely ignores them is arguably inferior to any of a number of possible combinations of the various components of human well-being that give them all importance.

One way to "resolve" the problem that arises when a comparison of two policies indicates one policy is better for one dimension of a two-dimensional goal and the other policy better for the other, is to declare one of the dimensions will be determinant and the other be ignored for all comparisons where such conflicts arise (and both dimensions will be accepted as goals for all comparisons where no such conflicts arise). In 1977 the US Federal Reserve was mandated by Congress with what has become known as its "dual mandate", to "promote effectively the goals of maximum employment, stable prices, and long term interest rates". 6 As witnessed by its policies subsequent to that, and most famously by the 1979 "Volker shock" which played such an important role in consolidating the introduction of neoliberalism in the US and soon thereafter the world, the US Federal Reserve "resolved" such cases of conflicts when they arose between the two dimensions of its mandated goal by ignoring the employment dimension. This of course is synonymous with saying that it really only had a one-dimensional goal, and only pretended to have a two-dimensional goal whenever its policies did not obviously disprove that, because the second dimension was popular with the public. Such a "resolution" is not a meaningful option for addressing the inherent problem of any really multi-dimensional goal, such as Cuba's prosperous socialism.

Relating this issue to Cuba, it is theoretically possible that some policy could better promote increasing prosperity than an alternative policy, but benefit less (or harm) the Island's process of building socialism (or vice versa). In such a case presenting the harmful aspect as well as the beneficial one is a necessary part of a proper economic evaluation. In that case there can be no simple automatic "more is better" decision rule. A social decision would need to be made by Cuba concerning the merits of "the economic trade-off" - or a different alternative

6 This is called "dual" because for economic reasons the last two of these three are considered a single dimension. For a short presentation on this mandate and the history of the ideas that gave rise to it by the US Federal Reserve itself, see Steelman (2011). 
would need to be identified whose benefits in one dimension did not bring with them harm to any other dimension of Cuba's economic goal.

\section{4. "First, Do No Harm”}

There is a "special case" where one can say that one vector is greater than the other: when one vector is greater than the other in at least one dimension, and not less in any dimension. ${ }^{7}$ For the evaluation of policies relative to a multidimensional goal, this becomes the requirement that one policy is better than the other in at least one dimension, and not worse ("do no harm" $)$ ) in any dimension. While mathematically called a "special case" since it is a subset of all possible magnitude relations between two vectors, it is asserted here that there are a large number of policies that could be incorporated into Cuba's evolving economy that would satisfy this concept of "better" than what exists.

A final comment in this background section is that determination of what policies should be pursued does not end the discussion about the proposed policies. At least two additional questions concerning the policies remain which are appropriate for academic and political discussion. First, what is the most effective way to implement the policy? And second, what is the appropriate pace for making the desired changes? This work will not address these two further concerns. The issue of the determination of what policies should be pursued, however, which is what this work does address, is a necessary prerequisite to subsequent further deliberations of how and how fast.

\section{Evaluating Six Policies for Building a Prosperous Socialism in Cuba}

This section illustrates the central theoretical point of this paper, the necessity to examine the various dimensions involved for a proper policy evaluation against a multi-dimensional goal, by considering six of the most fundamental and commonly discussed policies for improving Cuba's economy. These examples suggest that in practice it is very often, though not necessarily always, possible to design policies in such a way that their evaluation relative to all the dimensions of Cuba's economic goal does not cause the potential problem of the "trade-off between dimensions" inherent to any multi-dimensional goal.

7 Technically, this is a "weakly greater than" vectoral relation, and it includes as a subcase the "strictly greater than" vectoral relation where one vector is greater than the other in all dimensions.

8 From the Hippocratic Oath, written in the 5th century BC. 


\section{Raising Cuba's Labour Productivity}

The most fundamental consideration for improving the prosperity of Cuba's economy was given already in 1776 by Adam Smith, in the first two paragraphs of The Wealth of Nations:

The annual labour of every nation is the fund which originally supplies it with all the necessaries and conveniences of life which it annually consumes... According, therefore, as this produce ... bears a greater or smaller proportion to the number of those who are to consume it, the nation will be better or worse supplied with all the necessaries and conveniences for which it has occasion. (Smith 1985: 3)

The most fundamental long-term determinant of any country's prosperity is its labour productivity. The Lineamientos from 2011 and the three guiding documents from 2016/17 are permeated with broad proposals directed specifically at increasing productivity.

With state employment still constituting about two-thirds of the total in 2018 (ONEI 2019: ch. 7, table 7.2, p. 11), the productivity in state enterprises remains centrally, though not exclusively, important to Cuba's overall macroproductivity. The drive to increase state enterprise productivity began in the enterprises of the armed forces several years before the Special Period began in 1990, and came to be called perfeccionamiento empresarial over the following two decades. ${ }^{9}$ Following the adoption of the Lineamientos in 2011, the direction of this process of continual enterprise improvement was taken over by the Área de Perfeccionamiento de Entidades in the Comisión Permanente para la Implementación y Desarrollo de los Lineamientos that was created.

The Lineamientos from 2011 and the guiding documents from 2016/17 rest on the standard socialist position that socialism requires sufficient human productivity to be able to support its humanistic goals. The conceptually broadest of these documents, the Conceptualización, states explicitly:

The prosperous and sustainable consolidation of our socialism is attainable from the increase in labour productivity and economic efficiency, so that wealth is increased for its distribution with equity and social justice, raising the quality and the material and spiritual level of life of the people, based on [the social policy's] principles and values. (PCC 2017a: 43)

9 For a terse description as of 2004 of the prerequisites, basic operational concepts, preparatory steps and the stage of execution once certified of perfecionamiento empresarial, see Ecured (n.d.). 
One of many pieces of economic statistical information not published regularly and continuously by Cuba, which would be useful for evaluating the essential issue of the Island's progress in its efforts to raise its level of productivity, is information about the gains in state enterprise labour productivity made annually. Information appears irregularly and in different fora, particularly in the press. In 2019 it was reported that over the period since the adoption of the Lineamientos, 2011-17, productivity in state enterprises rose 57\% (Izquierdo Ferrer 2019), 8\% per year.

Increasing Cuba's labour productivity is something that promotes both dimensions of its economic goal of building a prosperous socialism.

\section{Ending Cuba's Dual Currency}

An official dual currency system was created in Cuba through Decree-Law 140 in August 1993. Notwithstanding problems that this contributed to immediately, such as the growth of inequality in Cuba, a strong case can be made, and this author maintains, that at the time it was implemented its advantages greatly outweighed its disadvantages. Among its several short-term advantages, the one with the greatest immediate economic impact was that it facilitated a greatly increased flow of remittances into Cuba. Beyond their obvious and important direct effect of slightly cushioning the implosion of personal incomes, this enabled the government to obtain significant quantities of foreign exchange, particularly through the associated TRDs (Tiendas de Recaudación de Divisas). At that moment a lack of foreign exchange was the greatest barrier to the government being able to obtain the inputs from abroad that it needed to be able to reactivate Cuba's crippled productive facilities.

Whatever advantages it might possibly be argued to still have today in the face of complete convertibility between the two currencies within Cuba, and accepting the important concern that eliminating it would have unequal effects on different sectors of the population, today Cuba's dual currency system has become one of the largest barriers to systematically building a more prosperous socialism in Cuba. Appraisals of competing economic proposals require various quantitative evaluations. A first problem is that the dual currency system has now become extremely complex with multiple exchange rates between the two legal tenders, one for individuals and several different ones for different types of enterprises. But more fundamentally problematic than the complexity, this entire collection of rates which are used to determine the dollar (or peso) value of the various parts of Cuba's production is, necessarily, all set administratively. Hence the value ascribed to the various outputs, or even to Cuba's total GDP, that would result from various potential economic policies, is not determined just by 
the resulting amounts of real production. Instead, it is also significantly determined by what the various exchange rates are administratively set at, for which no "economically rational" basis can exist. The existence of these multiple and arbitrary exchange rates, however, does not make Cuba's quantitative evaluation of the effectiveness of the new polices that it is developing meaningless, it does not mean that Cuba is proceeding blindly. But the multiple and arbitrary exchange rates do mean that Cuba is trying to quantitatively evaluate its new economic performance and various proposed alternatives looking through a pair of very dirty glasses.

One would have to look very hard to find a single economist inside or outside Cuba who is not for returning to a single national currency as soon as possible, regardless of which of five or ten different visons of what a socialist Cuba should look like they embrace, or if they are for restoring capitalism. The need for the elimination of the dual currency system was already expressed in the Lineamientos in 2011 (PCC 2011: 9), ${ }^{10}$ and has been promised by the government many times since then, including with indications of fairly short time frames for doing so. As of when this manuscript is being finished in November 2020, it seems to be certain that the CUC will cease to exist in December 2020. Without overlooking the existence of the problems from its elimination which will need to be addressed, this elimination of the second Cuban currency will promote both dimensions of Cuba's economic goal of building a prosperous socialism.

\section{Improving Cuba's Trading Relations}

Any small country, be it as developed as Belgium or as underdeveloped as Haiti, must operate as part of a larger economy through trade. For many (though not all) of its productive units to operate efficiently, they must operate on a scale larger than its national economy. The value chains that run from raw materials to finished products have too many steps for them to all be included in any national economy, except for some chains in continental economies such as for example China, India or the US. For Cuba to operate many of its productive units efficiently as discussed in the first point in this section, it must be able to import productive inputs. Of its total imports of 11.5 billion pesos of goods in 2018, 7.6 billion pesos were intermediate goods, while only 2.3 billion pesos were consumer goods (additionally Cuba imported 1.6 billion pesos in capital goods) (ONEI 2019: ch. 8, table 8.8, p. 18). To obtain the internationally convertible currencies needed for such imports, Cuba needs to have export markets

10 In the current guiding documents, items 19 and especial 40 in Lineamientos 2016-2021 (PCC 2017b). 
for both its final goods and services, and for the intermediate goods and services which are parts of international value chains which Cuba focuses on producing at levels above its nationally required scale.

In 1989 Cuba was thoroughly integrated into the Council for Mutual Economic Assistance (CMEA) headed by the USSR, carrying out $85 \%$ of its necessary trade, and its related financing and investment needs, with this larger economy. Within two years these relations had largely ended, and Cuba had to "integrate itself into the international economy". ${ }^{11}$ If a country is not part of some special trading agreement in which trade is fundamentally barter ${ }^{12}$ notwithstanding any accompanying accounting prices, then standard capitalist world trade requires buying in convertible currencies. Therefore, Cuba had to find immediately something it could sell to obtain the foreign exchange required to buy the imports its economy needed to operate. It accomplished this in the 1990 s very largely through the sale of a service, tourism, which developed explosively at that time almost ex nibilo. By the following decade foreign exchange earnings diversified with the sales of medical services and nickel joining tourism as top earners of foreign exchange.

The guiding documents of 2016/17 give significant attention to the problem that all Third World countries face, not only of developing a broader range of exports to the world market, but also of developing exports with high value-added. One economic advantage Cuba has over most other Third World countries is the level of education of its workforce. This is something that has come out of its project to build socialism, and beyond its broad social value, it economically opens the door to the possibility of developing knowledgebased exports.

Cuba earned 14.5 billion pesos from exports of goods and services in 2018. Contrary to most Third World counties, services dominated with $81.1 \%$ of the export earnings, while goods earned only 18.9\% (ONEI 2019: ch. 5, table 5.13, p. 22). By far the largest single category at 6.4 billion pesos was the knowledge-based category, Human Health and Social Care Services (ONEI 2019: ch. 8 , table 8.13 , p. 47), ${ }^{13}$ much larger than the widely discussed tourism earnings at 3.0 billion pesos (ONEI 2019: ch. 15, table 15.15, p. 16). ${ }^{14}$ Though much smaller, the non-traditional category of Telecommunications and the

11 For brief history of this immense reorientation see e.g. Quiñones Chang (2013).

12 Some important non-capitalist trading relations were established with Venezuela after 2000, although they did not approach the degree of integration achieved in CMEA. At present those trading relations have greatly deteriorated because of Venezuela's severe economic problems. 
Transmission and Provision of Services for Information at 722 million pesos (ONEI 2019: ch. 8, table 8.13. p. 47) was just below the largest of Cuba's simple goods exports, ores (primarily nickel) and scrap metals at 776 million pesos. It was well above traditional export earners such as tobacco products at 260 million pesos, and sugar products at only $180^{15}$ million pesos (ONEI 2019: ch. 8, table 8.11, pp. 22 and 21). These figures again indicate some success in diversifying, and in particular away from the stereotype of low value-added primary products of Third World counties.

The building-socialism dimension of Cuba's economic goal has a strong effect on what kind of trade policy the country finds acceptable to develop, and no policies concerning Cuba's trade policy can be meaningfully evaluated without taking this dimension of its economic goal into account. Most important in this regard, the US government has repeatedly declared that it intends to continue its severe embargo against Cuba (hereafter "blockade"16) as long as Cuba maintains its commitment to building socialism.

The cost of the blockade to Cuba is enormous. The majority of the effect operates through trade channels, although its impact on Foreign Direct Investment to be discussed in the next point is also massive. The blockade greatly increases the cost of Cuba's imports. Equally important, it thwarts many possibilities for exports, and hence also thwarts opportunities for the necessary development of new exports. Without any implication that the blockade is "the most important impediment to increased prosperity", the blockade must be considered among the most important barriers to the necessary expansion of the Island's trade. Prior to the current draconian reintensification of the blockade under Trump, the Cuban government estimated its yearly cost to the Island already to be $\$ 4.3$ billion (Cuba Debate 2019). That rose to $\$ 5.6$ billion under

13 Because of differences in accounting procedures, Table 5.13 lists total export service earnings at 11.764 billion pesos while Table 8.13 lists them at 11.290 billion pesos.

14 In Table 8.13 on export service earnings, tourism earnings do not appear as a separate entry, but rather they are scattered through many categories.

152018 was a bad year for sugar, earning only about half of what it did in 2016 and around $40 \%$ of what it earned in 2013-15 and 2017 (ONEI 2019: ch. 8, table 8.7, p. 18).

16 The US sanctions technically constitute an "embargo". The Cuban government has chosen to indicate by using the term "blockade" that this set of policies is much more harmful than a standard embargo. This is a result of the secondary and extraterritorial sanctions, and in particular the US claim to have jurisdiction over the use by anyone, anywhere, of the most-used international currency in the world, the US dollar. The term "blockade" reflecting this economic point will be used in this work. 
the Trump's intensified policies for 201917 (Reuters 2020), roughly now at a level representing a loss of $5 \%$ of the Island's GDP every year.

Improving Cuba's trading relations, notwithstanding the major problems for doing this caused by the US blockade, would promote both dimensions of Cuba's economic goal of building a prosperous socialism.

\section{Increasing Foreign Direct Investment (FDI)}

The Lineamientos from 2011 already considered a major increase in FDI to be important to Cuba's developing new economy, and the issue was expanded on in the guiding documents of 2016/17. Cuba faced two major barriers in accomplishing this objective, an external one and an internal one.

The external barrier has just been discussed in the last point concerning Cuba's trading relations, the US blockade. The two important things to reemphasise here in relation to Cuba's economic goal are that the blockade exists because of Cuba's commitment to trying to build socialism, and that its effects on Cuba's efforts to attract FDI are massive.

The internal barrier is Cuba's institutions and procedures for accepting FDI. Cuba has made important progress in reshaping these, improving them from very poor to mediocre. Although Cuba was thoroughly integrated into CMEA in 1982 as indicated above, its investment law adopted in that year was directed fundamentally at the possibility of FDI from the capitalist world. With minimal exceptions, the law lay dormant until the disintegration of CMEA that began a few years before the start of Cuba's Special Period. With the exceptional FDI opportunities that Cuba opened up after 1990, initially particularly in tourism, FDI really began. The 1982 law was quickly found to be very inadequate for arrangements for FDI with capitalist enterprises.

What followed was a process of continual improvement of Cuba's investment laws in order to promote FDI. Law 77 in 1995, Law 118 in 2014 and scores of enabling legislations and procedural changes, made major revisions and significant improvements to the investment process. But the same central problems remained, albeit mitigated. For a large number of potential investors, the investment

17 Because a central purpose for computing the losses is to be able to detail their extent to the world, Cuba computes the yearly costs for the 12 months from April to the following March, in order to be able to collect and process the data in time for the yearly discussion on the blockade in United Nations in October. The just-released calculation for 2019 given here is therefore for April 2019 to March 2020. Note that in late summer 2020 Trump greatly intensified the blockade beyond its level at the end of this most recent evaluation period in March 2020, which itself was the result of his major intensification of the blockade from spring 2018 forward. 
procedure is too bureaucratically complex, and connected to that and of great importance to a capitalist company because it is a great expense, it takes far too long. In 2015 then president Raúl Castro "criticized 'the excessive delays of the negotiating process,' and urged lawmakers to 'overcome the obsolete mentality full of prejudice against foreign investment'” (Xinhuanet 2019). In June 2019, the new president Miguel Diaz-Canal "called for greater creativity and agility in approving business proposals” (Xinhuanet 2019). He also included the concern, flowing from Cuba's desire for national self-determination and specifically from its commitment to trying to build socialism, that this had to be done "without harming our sovereignty" (Xinhuanet 2019). On 1 September 2019, a senior official from the Foreign Trade and Foreign Investment Ministry, Deborah Riva, indicated the continued existence and importance of this problem by announcing the latest improvements to the investment process as "another step in speeding up the negotiation process to increase the entry of foreign investment to Cuba" (Xinhuanet 2019).

In 2014 Cuba initiated an important policy to proactively help address this problem. An official Portfolio of Opportunities for Foreign Investment was presented at the Havana International Fair in November of that year, soliciting bids for 246 specified projects, worth $\$ 8.7$ billion. This policy has been renewed annually to the present. ${ }^{18}$

While Cuba regularly released information on aggregate foreign investments inflow from 1993 to 2001, since then it has almost entirely ceased to disclose this information, ${ }^{19}$ due to the continual efforts by the US to disrupt such investments. In 2007 the Minister of Foreign Investment and Economic Collabouration, ${ }^{20}$ Martha Lomas, announced that in 2006 Cuba had achieved a record FDI of \$981 million, 22\% above the previous year (Europa Press International 2007). Given that this was during the world commodity boom and at a time of strong growth of the Cuban economy which has not been equalled since the world Great Recession of 2008/9, that very likely continues to be the highest, or at least close to the highest, FDI into Cuba ever archived in a single year. ${ }^{21}$

18 For copies of all Cuba's offers over the years, and from that an understanding of what type of FDI Cuba is soliciting, see US-Cuba Trade and Economic Council (2018).

19 The irregular quantitative FDI announcements that it has made since then are almost always the amounts of new agreements, rather than the economically more relevant values of actual FDI flows into Cuba occurring in a given year.

20 This ministry merged into the Ministry of Foreign Trade and Foreign Investment in 2009 .

21 This statement is supported by the lower values estimated by the Economist Intelligence Unit for 2010 and 2011 (EIU 2012, 2011), and the figure reported for the government's expected FDI inflow for 2018 (Frank and Rathbone 2018). 
At the time of the adoption of the new investment law in 2014, the Minister for Foreign Trade and Foreign Investment, Rodrigo Malmierca, said that Cuba wanted to attract $\$ 2$ to $\$ 2.5$ billion per year in FDI (Trotta 2014). The figure of $\$ 2.5$ billion has become widely used since then to indicate Cuba's desired level, ${ }^{22}$ which would be roughly $2.5 \%$ of the Island's GDP. For comparison, note that the United Nation's Economic Commission for Latin America and the Caribbean calculated the average FDI to GDP ratio for Latin America in 2015 to be just under 2.5\%, while that for the Caribbean was just over 4\% (ECLAC 2015: 37). While again even very rough figures on yearly FDI into Cuba today are not available, $\$ 2.5$ billion is clearly very far above any realistically conceivable estimate of current FDI, extrapolating from the levels from 10 and 15 years ago given above, and considering the current state of Cuba's economy relative to then.

Contingent on it being done as intended "without harming Cuba's sovereignty", greatly increasing FDI into Cuba would make an important contribution to both dimensions of Cuba's economic goal of building a prosperous socialism.

\section{Increasing Self-Employment}

On 8 September 1993, Decree-Law 141 was passed listing over 100 occupations suitable for Trabajo por Cuenta Propia ${ }^{23}$ (self-employment), with a number of others added subsequently. It was designed to make employment available for unemployed people, ${ }^{24}$ provide goods and services that the state enterprises were not supplying adequately (if at all) and increase national productivity and efficiency. From about $1 \%$ of the workforce in 1989 prior to the start of the Special Period, self-employment exploded to about $5 \%$ by the end of 1995 , over 200,000 people. It then dropped below that and remained fairly stable until 2010, after which it experienced a second major expansion, taking it to about 580,000 people by the end of 2018 , about $13 \%$ of the workforce (Agencia EFE 2019). Reflecting the importance of this category that had developed over the first two decades of the new economy, the Lineamientos from 2011 frequently referred to self-employment when discussing forms of property and management other than the "socialist property of all the people" that was to dominate the economy.

22 As one example among many where it was subsequently used, and for a short informative article giving a Cuban perspective on Cuban FDI, see Rodríguez (2015).

23 This expression used in Cuban law and popular discourse refers to non-agricultural self-employment.

24 Which state enterprises were not able to offer at that time. 
In relation to the prosperity dimension of Cuba's economic goal, this policy of expanding self-employment to its current level has shown itself over more than a quarter century to have been very successful. Goods and services that otherwise would not have been available were created and consumed, and people who became economically active were clearly more productive and efficient than if they had remained economically inactive. In relation to the building-socialism dimension of Cuba's economic goal, neither selfemployment, nor the necessary accompanying markets for exchanging production from self-employment, can ever per se serve as the basis for capitalism (or in the specific case of Cuba, its restoration). ${ }^{25}$ Nevertheless, in the specific conditions of Cuba today, self-employment has the potential to generate a degree of "too much inequality", producing levels that many socialists feel would seriously damage the social solidity required for a process of building socialism. Hence the proposal to expand self-employment to its current levels becomes supportive of Cuba's economic goal only once it is determined to be done in a way that will not generate a degree of inequality that would harm its socialism-building dimension. Guideline 3 of the Lineamientos is directed specifically at that concern, forbidding the concentration of property by the self-employed and all other legal or natural persons engaged in non-state forms of management of productive resources which could generate such unacceptable inequality (PCC 2011: 11).

Contingent on measures implemented to prevent self-employment from generating a level of inequality that harms the process of building socialism, under existing conditions in Cuba expansion of self-employment to its current level, or possibly to a greater level, will serve its economic goal.

\section{Increasing Private Property in the Means of Production}

What had been the category of self-employment in the Lineamientos of 2011 was subsumed into the much broader and therefore different category of "private property" in the three current guiding documents from 2016/17

25 Very briefly, capitalism is a specific form of exploitation, where a minority that owns the large majority of capital appropriates through the legal structures many products created by the work of the majority. While markets are necessary for the capitalist circuits of capital that allow this exploitation through the exchange of the product of one's labour power for a wage, markets themselves do not imply capitalism. The logical lack of markets implying capitalism, or even capital, is underlined by noting that in his master work on capitalism, Marx described in the first three chapters how markets worked and could link disparate self-employed, in a presentation in which capital did not exist. 
(PCC 2017a: section 2.1.d, pp. 29 ff.). One part of this new category is the old trabajo por cuenta propia, now defined in more detail:

Small businesses (negocios), which are basically carried out by the worker and his family. These do not constitute business (empresarial) entities or have legal personality. (PCC 2017a: section 2.1.d.1, p. 30)

But now a whole new form appears, standard capitalist small and medium enterprises (SMEs), with their hired and salaried workforce:

Private companies (empresas) of medium, small and micro scales according to the volume of activity, number of workers and corporate purpose, which are recognized as legal entities. (PCC 2017a: section 2.1.d.2, p. 30)

The 1976 Constitution that was in force when self-employment was expanded in the new economy in the 1990s committed the state to oppose "exploitation of man by man" (constituteproject.org n.d.: Article 9, p. 9), understood as hiring labour. But naturally over time many of the self-employed nevertheless began to clandestinely hire people beyond family members. ${ }^{26}$ To address this issue, which represented both a breakdown of the law and lost tax revenues, the government created a category among the authorised self-employed activities, "workers hired as labour by private business owners". In mid-2013 when there were 429,458 Cubans designated as self-employed, being hired as a labourer was the largest of the 181 authorised activities, representing $18 \%$ of the total selfemployed. Just under half of the authorised self-employment activities, 83, were allowed to hire labour this way (Café Fuerte 2013).

Unlike the truly self-employed in the earlier category of self-employed, the SMEs do have the clear potential to be the basis for the growth of capitalism to a scale that would threaten the building-socialism dimension of Cuba's economic goal. The government is presently working on general regulations for these new SMEs, and in particular on the regulations concerning their hired labour. Just as was previously noted that the Lineamientos opposed anyone who was self-employed becoming too large economically, the Conceptualización

26 Of course one's degree of kinship is irrelevant to the issue of exploitation, but "family labour" is a loose term that includes different economic relations. If a person pays a wage to some "distant cousin", but also a close family member, and has claim to all produced or earned by the employee's work, that is exploitation of family labour. If family members simply work as part of the family unit and the product of all the labour belongs to the family as a whole, there is no economic exploitation involved. 
similarly indicates that the state will apply "polices, norms and regulations" to limit the SMEs. These will not only concern their size (which in the first instance will preclude the suggestive but imprecise category of "large enterprises"), but also the scope of their activity, their profits and their "private appropriation of the work of others" (PCC 2017a: 30).

Under the assumption that the future SMEs will be able to provide goods and services that neither the state enterprises nor the self-employed can currently provide, they will contribute to the prosperity dimension of Cuba's economic goal. Given this positive contribution to one dimension of Cuba's economic goal, if the government can restrict the new SMEs to "doing no harm" to the buildingsocialism dimension of its economic goal, as it projects that it will be able to do, then the SMEs will contribute to Cuba creating its prosperous socialism. If to the contrary the creation and expansion of the SMEs as part of Cuba's evolving new economy harm the Island's process of building socialism, despite the measures the government takes to prevent that and despite the government's conviction that those measure will assure they do not, then the creation and subsequent expansion of SMEs cannot be said to serve Cuba's economic goal.

\section{Conclusion}

Policies adopted over the last three decades to increase labour productivity, foreign trade and FDI into Cuba, in the way they have been adopted, have promoted all dimensions of Cuba's economic goal of building a prosperous and sustainable socialism. Policies to further increase all of these, and in addition a policy to eliminate its dual currency system, all in ways consistent with all the dimensions of its economic goal, are a high priority for Cuba today.

Under the conditions that Cuba has faced for the last three decades, creating the large self-employed sector has made an important contribution to increasing the Island's prosperity. Given that too much inequality will harm the process of building socialism, the government has implemented various policies over the years to restrict the amount of inequality that has resulted from the expanded self-employment. ${ }^{27}$ This author shares the view of the government that the expansion of the genuine self-employment to its current level has served all dimensions of Cuba's economic goal. The government has frequently indicated the possibility that self-employment could expand to twice its current level.

27 These frequently changing policies, motivated by this concern, have been a favourite target for criticism of the Cuban government by the international press and by commentators who are opposed to the building-socialism dimension of Cuba's economic goal. 
Whether it will be allowed to do so or not must depend on if, under the actual conditions that come to exist in the near future, doing so will promote all the dimensions of Cuba's economic goal.

The analysis and discussion of the proposed SMEs further underlines the necessity to consider all dimensions of Cuba's multi-dimensional economic goal. Under the assumption that the SMEs will be able to provide goods and services that the state sector and the self-employed sector cannot ${ }^{28}$ provide, they will contribute to Cuba's prosperity. Since they will involve introducing a significant extension of capitalist relations of production into the Cuban economy, it is particularly important to consider if introducing them will harm the building-socialism dimension of Cuba's economic goal. ${ }^{29}$ The Cuban government has indicated that it has considered this and believes that, through properly designed norms, policies and regulations, the SMEs can both operate effectively and do no harm to Cuba's project of building socialism. If these two beliefs are both correct, then the proposed SME new form of property and production will, like the other five examples of economic policies considered in this article, serve to promote in Cuba today its economic goal of building a prosperous and sustainable socialism.

\section{References}

Agencia EFE (2019) “Cuba sobrepasa los 600.000 trabajadores en el sector privado", 9 July. Available at https://www.efe.com/efe/america/economia/cuba-sobrepasa-los600-000-trabajadores-en-el-sector-privado/20000011-4019457. (Accessed November 2020.)

Café Fuerte (2013) “Cuba has over 400,000 self-employed”, Havana Times, 25 June. Available at http://www.havanatimes.org/?p=95385. (Accessed November 2020.)

Carroll, Lewis (1865) Alice's Adventures in Wonderland. Reprinted in Alice's Adventures in Wonderland and Through the Looking-Glass and What Alice Found There. Oxford: Oxford University Press, 2009.

28 "Cannot" here means in Cuba as it exists today, and in the short term. While it is an important academic question if a highly developed socialism will have any role for private property in the means of production, either with or without hired labour, this essay takes the position that question is not historically relevant until the state can provided the services such sectors provide today. Once it can, that is when the people living in that future society should decide this question on the basis of what structure they feel will best support their human development.

29 When considering what danger this could present to the building-socialism dimension of Cuba's economic goal, it is relevant to recall the fact that the CCSs (Cooperativas de Créditos y Servicios), whose members and salaried workers together today approach 200,000, already produce (and since 1960 have) under capitalist relations. 
constituteproject.org (n.d.) Cuba's Constitution of 1976 with Amendments through 2002. Available at https://www.constituteproject.org/constitution/Cuba_2002.pdf?lang=en. (Accessed November 2020.)

Cuba Debate (2019) "Parlamentarios condenan en La Habana el bloqueo de Estados Unidos contra Cuba", 9 October. Available at http://www.cubadebate.cu/noticias/2019/10/09/parlamentarios-condenan-en-la-habana-el-bloqueo-de-estados-unidos-contra-cuba/. (Accessed November 2020.)

ECLAC (Economic Commission for Latin America and the Caribbean) (2015) Foreign Direct Investment in Latin America and the Caribbean. Santiago, Chile: ECLAC. Available at https://repositorio.cepal.org/bitstream/handle/11362/38215/4/S1500534_ en.pdf. (Accessed November 2020.)

Ecured (n.d.) "Perfeccionamiento Empresarial." https://www.ecured.cu/Perfeccionami ento_empresarial. (Accessed November 2020.)

EIU (Economist Intelligence Unit) (2011) Country Report: Cuba. London: EIU.

EIU (Economist Intelligence Unit) (2012) Country Report: Cuba. London: EIU.

Europa Press International (2007) "Cuba. - Cuba registra un récord de inversión extranjera en sus ingresos en 2006 y considera así reorganizada su inversión", 26 June. Available at https://m.europapress.es/internacional/noticia-cuba-cuba-registra-record-inversionextranjera-ingresos-2006-considera-asi-reorganizada-inversion-20070626234157. html. (Accessed November 2020.)

Frank, Marc and Rathbone, John Paul (2018) "Cuba in drive to attract foreign investment”, Financial Times, 8 May. Available at https://www.ft.com/content/9ef0f1184fcd-11e8-a7a9-37318e776bab. (Accessed November 2020.)

Granma (2017) "Third Central Committee Plenum approves documents on the updating of the Cuban economic and social”, 22 May. Available at http://en.granma.cu/ cuba/2017-05-22/third-central-committee-plenum-approves-documents-on-theupdating-of-the-cuban-economic-and-social-model. (Accessed November 2020.)

Granma (2019) “Communist Party of Cuba Central Committee holds IX Plenum”, 12 April. Available at http://en.granma.cu/cuba/2019-04-12/communist-party-of-cubacentral-committee-holds-ix-plenum. (Accessed November 2020.)

IFES (International Foundation for Electoral Systems) (2020) "Election Guide. Cuba", Available at https://www.electionguide.org/countries/id/56/. (Accessed November 2020.)

Izquierdo Ferrer, Lissett (2019) "Sistema empresarial Cubano: Cambios necesarios", Cuba Debate, 1 February. Available at http://www.cubadebate.cu/cuba/2019/02/01/ sistema-empresarial-cubano-cambios-necesarios/. (Accessed November 2020.)

NAPP (National Assembly of Peoples Power) (2017) "Report on the analysis of the documents of the 7th PCC Congress", Granma, 2 June. Available at http://en.granma.cu/ cuba/2017-06-02/report-on-the-analysis-of-the-documents-of-the-7th-pcc-congress. (Accessed November 2020.)

ONEI (Oficina Nacional de Estadística e Información) (2019) Anuario Estadística de Cuba. Available at http://www.onei.cu/aec2018.htm. (Accessed November 2020.)

PCC (Partido Comunista de Cuba) (2011) Lineamientos de la Política Económica y Social del Partido y la Revolución. Available at https:/www.pcc.cu/sites/default/files/documento/ pdf/20180426/lineamientos-politica-partido-cuba.pdf. (Accessed November 2020.) 
PCC (2016a) Conceptualización del Modelo Económico y Social Cubano de Desarrollo Socialista. Plan Nacional de Desarrollo Económico y Social hasta 2030: Propuesta de Visión de la Nación, Ejes y Sectores Estratégicos. [Note this is two documents.] Available at www.granma.cu/file/pdf/gaceta/CopiaparaelSitioWeb.pdf. (Accessed November 2020.)

PCC (2016b) Actualización de los Lineamientos de la Política Económica y Social del Partido y la Revolución para el Período 2016-2021. Available at http://www.granma. cu/file/pdf/gaceta/01Folleto.Lineamientos-4.pdf. (Accessed November 2020.)

PCC (2017a) Conceptualización del Modelo Económico y Social Cubano de Desarrollo Socialista. Available at http://www.granma.cu/file/pdf/gaceta/Conceptualizaciónde lmodeloeconomicosocialVersionFinal.pdf. [Note missing accents on "económico" and "Versión" in this web address.] (Accessed November 2020.)

PCC (2017b) Lineamientos de la Política Económica y Social del Partido y la Revolución para el Período 2016-2021. Available at http://www.granma.cu/file/pdf/gaceta/ Lineamientos2016-2021VersiónFinal.pdf. (Accessed November 2020.)

Quiñones Chang, Nancy (2013) “Cuba's insertion in the international economy since 1990", in Al Campbell (ed.), Cuban Economists on the Cuban Economy. Gainseville, FL: University Press of Florida.

Reuters (2020) “Cuba says U.S. trade embargo cost more than \$5 billion last year", 22 October. Available at https://www.reuters.com/article/us-cuba-usa-idUSKBN2772L1. (Accessed November 2020.)

Rodríguez, José Luis (2015) "Valoraciones externas sobre la inversión extranjera en Cuba”, Cuba Debate, 5 November. Available at http://www.cubadebate.cu/opinion/ 2015/11/05/valoraciones-externas-sobre-la-inversion-extranjera-en-cuba/. (Accessed November 2020.)

Smith, Adam (1985[1776]) An Inquiry into the Nature and Causes of the Wealth of Nations. New York: Modern Library College Editions.

Steelman, Aaron (2011) “The Federal Reserve's 'dual mandate': the evolution of an idea”, Economic Brief, December, The Federal Reserve of Richmond. Available at https:// www.richmondfed.org/-/media/richmondfedorg/publications/research/economic brief/2011/pdf/eb_11-12.pdf. (Accessed November 2020.)

Trotta, Daniel (2014) “Cuba approves law aimed at attracting foreign investment”, Reuters, 29 March. Available at https://www.reuters.com/article/us-cuba-investment/cubaapproves-law-aimed-at-attracting-foreign-investment-idUSBREA2S0EJ20140329. (Accessed November 2020.)

US-Cuba Trade and Economic Council, Inc. (2018) “Cuba releases 2018-2019 portfolio of opportunities for foreign investment", 2 November. Available at https://www. cubatrade.org/blog/2018/11/2/cuba-releases-2018-2019-portfolio-of-opportunitiesfor-foreign-investment. (Accessed November 2020.)

Xinhuanet (2019) “Cuba amends law to attract more foreign investment", 2 August. Available at http://www.xinhuanet.com/english/2018-08/03/c_137365873.htm. (Accessed November 2020.) 